\title{
Educational topics for school from the perspective of professionals in the Mobile Emergency Service
}

\author{
Temas educativos para escolares sob a perspectiva dos profissionais \\ do Serviço de Atendimento Móvel de Urgência \\ Temas educativos para la escuela desde la perspectiva de los \\ profesionales en el Servicio de Emergencia Móvil
}

Larissa Larie Mota ${ }^{1}$, Selma Regina de Andrade ${ }^{2}$

${ }^{1}$ Serviço de Atendimento Móvel de Urgência. Lages, Santa Catarina, SC, Brazil.

${ }^{2}$ Universidade Federal de Santa Catarina. Departamento de Enfermagem. Florianópolis, Santa Catarina, SC, Brazil.

\section{ABSTRACT}

Objective: To systematize, with professionals from the Mobile Emergency Care Service of Santa Catarina municipality, the main issues for the development of an educational tool of attention to the emergency room, dedicated to the school-age population. Method: Qualitative study, conducted through meetings in the focus group format, with 19 professionals who develop their activities in the city Emergency Mobile Emergency Service. Data were categorized and analyzed using thematic analysis technique. Results: The contents discussed at the meetings were grouped into four thematic categories: The Mobile Emergency Service and the school: education and health promotion for children; As the Mobile Emergency Care Service works: What is important to know ?; Something's wrong, what now? and; We are nearly finished, give your opinion. Conclusion: The specific issues arising from the meetings contributed to the production of an educational tool on the activities of the Mobile Emergency Service, which may be used by the School Health Program to promote health education in the care area to the emergency room with the population schoolchildren.

\section{DESCRIPTORS}

Emergency Medical Services; School Health; Health Promotion; Health Education; Family Health Strategy.
Correspondence Addressed to:

Selma Regina de Andrade

Campus Reitor João David Ferreira Lima

Departamento de Enfermagem, Bloco I

sala $401,4^{\circ}$ andar

CEP 88.040-900 - Florianópolis, Santa Catarina,

SC, Brasil

selma.regina@ufsc.br
Received: 26/03/2015

Approved: 14/11/2015 


\section{INTRODUCTION}

There is a consensus in the health field that the emergency service, before the hospital doors, can reduce suffering, increase the chances of survival and reduce physical and emotional sequelae. Developing intervention strategies to inform the public about the operation of the Mobile Emergency Care Service $\left(S A M U^{1}\right)$, contributes to changes and implies interaction, sharing knowledge and practices, with the intention that users know how to identify risk situations, when they ask for help, what information should be available, as well as raise awareness to the correct resource utilization.

The ease of access to the $S A M U$, via telephone toll-free direct dialing, 192, can be understood also as a negative aspect, as it ends up encouraging misuse. The high rates of prank phone calls, the incorrect use of the service, the delay in the care of patients who actually require intervention, and the big volume of irrelevant demand, understood as the cases where there is not life-threatening situation ${ }^{(1)}$, slow down the service and lead to economic and welfare losses.

Although the entire population is taken as target of care provided by $S A M U$, a positive impact of consistent educational activities aimed at school-age population can provide good outcomes, with long-term results, given the assumption that children and youth are individuals in a constant process of training and also by influencing opinions and behavior in their social and family nuclei.

The School Health Program (SHP), established in 2007, aims to contribute to the integral training of students of public network for basic education. Activities related to the prevention, promotion and health care are expected to be developed within the school environment, by professional from the Family Health Strategy teams (FHS), responsible for attending the community where the school is located. In the city of study, the SHP is coordinated by the Municipal Secretariat of Education, and throughout the year 2013, the proposal was presented to professionals in the fields of health and education, who participated in training and planning of activities for the year $2014^{(2)}$.

Taking the topic of $S A M U$ activities into the schools is undoubtedly a way to make children aware of the importance and seriousness of this service. Addressing these and other topics among children, reinforcing the knowledge of $S A M U$, underscores the importance of this service in which minutes are worth lives, and awakens the sense that it should be used with awareness and responsibility.

Initiatives like this are already being placed in Brazil. In 2007, the government of the Federal District launched "the little $S A M U$ project" to disseminate and educate school children enrolled in primary school ( $1^{\text {st }}$ to $9^{\text {th }}$ grade), on the importance and purpose of $S A M U^{(3)}$. In the little $S A M U$ project, professionals working at the

1 Its acronym is well known in Brazil and refers to the name of the service in Portuguese (Serviço de Atendimento Móvel de Urgência).
$S A M U$ go to schools to develop educational activities with the children, a point which differs from the proposal presented here. In this study, the proposal was to create an educational instrument, which subsidizes the actions developed by the FHS professionals in schools in their jurisdiction, addressing emergency situations clearly at school, and alert them to the correct use of $S A M U$, since we clarify how this works.

To this end, we present the question: What are the topics that $S A M U$ professionals consider necessary for the development of an educational instrument about attention to the emergency care? To answer this question, this study aimed to systematize, together with the $S A M U$ staff from a city of the state of Santa Catarina, the main issues for the development of an educational instrument of attention to the emergency care, dedicated to the school-age population.

\section{METHOD}

The 19 professionals who participated in the study remained virtually the same in all the FG, with average fluctuation of 10 participants, a fact that determined the format of meetings with the proposition of new topics or deepening in every meeting. Aspects built in previous meetings were briefly addressed to contextualize each subject who was participating for the first time. For each meeting, the central topic was highlighted, specific topics related to health education; emergency care service; the emergency situations; and final evaluation in addition to the stimulus for discussion, setting, in each meeting, a group for categorical analysis (Box 1).

The specific topics included in the first meeting (Health Education) were: Training of aware and committed Citizens; Increased life expectancy of users; Children and adolescents as the population cared; Improving care; Reduction of pranks; Little $S A M U$ project permeated various moments of discussion; PSE $\mathrm{x}$ municipality study; health professionals as educators. At the second meeting (emergency care): Difference between urgency and emergency; Who should call SAMU; Who answers the calls; Data that must be provided during the telephone call; Where are the cars; Number of teams working in the city. In the third meeting (the urgency situations): Fainting; seizures; cardiopulmonary arrest (CPA); Hypoglycemia and hyperglycemia; Airway obstruction by a foreign body (FBAO); acute myocardial infarction (AMI); accidents (transit and domestic); haemorrhages and cerebrovascular accident (CVA). In the fourth meeting (final evaluation): Suggestions for inclusion in educational instrument: inter-hospital and inter-city referrals; Drowning. Name suggested to the instrument: "IOW SAMU" (Informative and objective work for SAMU). 
Box 1: Summary of Focus Group meetings. City`s Mobile Emergency Care Service (SAMU), 2012

\begin{tabular}{|c|c|c|c|c|}
\hline & 1st meeting & 2nd meeting & 3rd meeting & 4th meeting \\
\hline Date & $25 / 10 / 12$ & $14 / 11 / 12$ & 19/11/12 & $28 / 11 / 12$ \\
\hline $\begin{array}{l}\text { Number of } \\
\text { participants }\end{array}$ & 10 & 13 & 06 & 09 \\
\hline $\begin{array}{l}\text { Central topic } \\
\text { (Key question) }\end{array}$ & $\begin{array}{l}\text { Do you think it is } \\
\text { important for children to } \\
\text { know about the service } \\
\text { SAMU offers? }\end{array}$ & $\begin{array}{l}\text { What information about } \\
\text { the operation of SAMU do } \\
\text { you consider important for } \\
\text { children to know? }\end{array}$ & $\begin{array}{l}\text { What urgent and } \\
\text { emergency situations } \\
\text { do you highlight to be } \\
\text { addressed to the school- } \\
\text { age population? }\end{array}$ & $\begin{array}{l}\text { Are we missing some } \\
\text { information? } \\
\text { Does any item need to } \\
\text { be added, removed, or } \\
\text { relocated? }\end{array}$ \\
\hline Specific topics & Health education & The urgent service & Urgent situations & Final evaluation \\
\hline Stimuli & $\begin{array}{l}\text { Welcoming video and } \\
\text { figures of projects and } \\
\text { educational campaigns }\end{array}$ & $\begin{array}{l}\text { Cartoons about the service } \\
\text { provided by SAMU }\end{array}$ & Welcoming video & $\begin{array}{l}\text { Presentation of the pre- } \\
\text { structure educational } \\
\text { instrument. } \\
\text { closure video }\end{array}$ \\
\hline Thematic categories & $\begin{array}{l}\text { SAMU and the school: } \\
\text { education and health } \\
\text { promotion for children }\end{array}$ & $\begin{array}{l}\text { How does SAMU work: } \\
\text { what is important to know? }\end{array}$ & $\begin{array}{l}\text { TThere's something wrong, } \\
\text { now what? }\end{array}$ & $\begin{array}{l}\text { We are nearly finished, } \\
\text { give your opinion. }\end{array}$ \\
\hline
\end{tabular}

The results of the focus group meetings were grouped into four thematic categories: The Mobile Emergency Care Service and the school: education and health promotion for children; How does the Mobile Emergency Care Service works: what is important to know?; There is something wrong, now what? and; We are nearly finished, give your opinion.

\section{The Mobile Emergency Care Service and the school: EDUCATION AND HEALTH PROMOTION FOR CHILDREN}

At the meeting, we presented the study objectives, methodology, ethical issues and the means records the information during the discussions, and read and sign the Consent Form (CF).

To start the activity, a welcoming video was presented to the group, for the reflection of professional practice in emergency situations. Other stimuli (figures) representing projects and awareness campaigns/education, already structured in other cities in the country were used. Next, we went to the chosen topic for this day: Do you think it is important for children to know the service SAMU offers?

\section{In fact, we will reinforce what not to do than what to do. [...] We know that children take home what they learn, [...] poking father, mother, brother and everyone to do the right thing, unlike people who sometimes le- arn and do not share with their own family [...] (R2).}

Discussions touched the vast majority of planned specific topics, including those prepared for the second meeting, which were incorporated into the first. Therefore, the discussions on health education, and the need for training of citizens who are aware and committed, the increase in life expectancy of users, and children and adolescents as future population cared. The group also addressed issues such as the improvement of the care provided, a reduction of prank phone calls, the Little SAMU Project, the reality of the SHP in the city of the study, and the educational role of SAMU`s professionals, beyond the concern to clarify among health professionals as SAMU is organized.

\section{How the Mobile Emergency Care Service works: WHAT IS IMPORTANT TO KNOW?}

The topic proposed to participants at this meeting was: What information about the operation of SAMU do you consider important for children to know?

Participants commented on the difficulties faced during the calls, particularly with regard to ignorance on the part of the population in relation to the service provided by SAMU, in addition to numerous distorted comparisons with other services that also offer pre-hospital care, but in another level of care.

Firefighters have marketing, lack much of that for
SAMU [...] lack the presence of an administration
[coordination] for this (R15).
Training [informing] the basic health unit, children
and the school. [...] Lack of information from the
school personnel (R11).

Three cartoons about SAMU were presented. Two of them portrayed a satirized service, showing delay in treatment, and another implied drop in the number of deaths after the implementation of the service. The group discussed the items listed as specific topics in the guide of topics dealing about the importance of clarifying the difference between urgent and emergency care.

Another specific issue addressed was who should call SAMU, a reference only to accept reliable or credible the telephone calls made by adults. Also touched to clarify users who answers calls and data that must be provided during the phone call.

\section{To inform the children the importance of reference, the more information the better (R7).}

The meeting was concluded by addressing the importance of informing where are the ambulances and the number of teams to serve the entire city, as SAMU`s professionals are usually questioned about the delay to reach the site of care. 
All information is valid. No one knows about the transfers, inter-hospital transport [...] interceptions [...] support to the Basic Support Unit and Advanced Support Unit and vice versa (R11).

\section{THERE IS SOMETHING WRONG, NOW WHAT?}

To this point, the stimulus is a short video that represent in a burlesque and fictitiously way, care in a hospital emergency room. The foregoing topic was: What urgent and emergency situations do you highlights to be discussed among the school-age population? Participants discussed the relevance of many diseases, including and excluding various items. In many instances, the selection was based on personal experiences and for discussions on which diseases should compose the educational instrument, relevant comments emerged to the subject of this research, among which are:

\begin{abstract}
We need to encourage in them the responsibility they have. Show that what he/she is saying is true, will involve a number of professionals who are ready to help. And to show that the game has a cost and generates a number of other situations (R11).
\end{abstract}

Many children do not know the address of where they live. So you have to guide parents to leave the address written to them. [...] Say that while they are going through a prank call, there might be another person in real need, and the resource will not be there because they are working ( $R 7)$.

The group discusses all proposed specific topics, including and excluding topics, such as hypertensive emergencies. Then, after establishing the aggravation and adding new topics to the specific topics identified in the guide, this was composed as follows: Fainting, including seizure and PCR crisis; Hypoglycemia and hyperglycemia; FBAO; AMI; Accidents covering traffic accidents (road accidents) and domestic accidents (poisoning, accidents with poisonous animals, burns, electric shock, injuries in general and bleeding); and stroke.

After performing this step, it was possible to establish a pre-structure educational instrument comprised of concepts and guidelines to facilitate the school-age population included in the SHP. In addition, identifying a risk or aggravation to health and how to properly act in front of it, based on principles of Pre-Hospital Care (PHC), until the arrival of specialized assistance, either through the SAMU or the fire department when required.

\section{WE ARE NEARIY FINISHED, GIVE YOUR OPINION!}

The last meeting sought to confirm aspects built in previous meetings, providing opportunities to change any proposed item, as suggested by the topics worked: Missing or left some information? Does any item need to be added, removed, or relocated? Also, a pre-structure of the educational instrument was delivered to each participant, in order to facilitate the visualization of topics and encourage individual review and collective reading. In addition to adding to drowning injuries listed in the previous meeting, there were suggestions to include on inter-hospital and intercity transfers.

One participant suggested that the educational instrument should be called "IOW SAMU" (Informative Objective Work about SAMU), generating a lot of fun and approval by the others. To end the activities, we used a motivational video.

At the end of the meetings we produced an educational instrument about SAMU, a proposal from the perspective of professionals working in this service, available on the website of the Professional Master Degree in Management of Care in Nursing at UFSC.

\section{DISCUSSION}

The study shows that professionals who develop their activities in SAMU, identify the need to inform the school-age population about health care. Incorporating health promotion concepts to daily life of the population means teaching them the appropriate use of health services, which in this study is characterized by SAMU, in addition to promoting the ability to make assertive decisions on emergency situations ${ }^{(1)}$.

The professionals who participate in the meetings, sometimes mentioned during the calls, try to clarify some aspects of the service, especially when they realize that citizen is altered due to stress involved in the situation, but these initiatives are incipient and require more comprehensive strategies to promote a change in SAMU users' perception.

Every effort for health education is not solid enough to effective change if the sector develops its actions in isolation, that is, without allying with others. The integration network proposes that areas of greater and lesser complexity of care are articulated, in order to provide support to the health sector, such as the sectors of science and technology, transport, infrastructure and education ${ }^{(6)}$. For the emergency service is no different, as the realization of the integrality of care is a challenge to $\mathrm{SUS}^{2}$, involving its agents (workers) and other social actors performing assistance. Several authors point out the interaction between sectors as a way to share in education a more effective health, and enter the school environment with educational proposals on health meeting this premise.

It is known that in Brazil, Schools Promoting Health are gaining more space for its notoriety and to admit that there are a number of actions that can be developed with the aim of sensitizing people to take control of the various aspects that influence their health, reducing unfavorable and encouraging the performance of aspects "protective and healthy"(7).

Even in schools where the educational project does not follow these patterns, the promotion of health education established on a permanent and continuous basis is essential to, because they need to be able to foster in children the acquisition of the ability to make aware and responsible

2 Unified Health System in Brazil called Sistema Único de Saúde (SUS) in portuguese. 
individual choices, that will subsidize the construction of a healthy life style and critical citizenship ${ }^{(7)}$. The knowledge acquired during the period of school life tends to accompany the subject throughout his/her life ${ }^{(8)}$, and introduce notions of how to proceed on an urgent health problem even before the arrival of a professional, aiming to familiarize children with the subject, in addition to supporting actions and correct access to the system. That is, the school provides a privileged environment for the implementation of health education strategies for being a sector which includes such activities ${ }^{(9)}$.

The group highlighted the education sector as important in this process, since children socialize with their family and friends what they learn in school. This is because there is the development of interest in shared topics, covering all those involved in contact with these children, and so the knowledge is transferred in a relaxed way.

The FHS was established as reorganizing primary care network in Brazil, and is considered the main access to users in SUS. Even with all this notoriety, its effectiveness is still tied to fulfilling spontaneous demand, weak surveillance and health promotion actions, curative focus and centered on the hegemonic model of medical professional field ${ }^{(10)}$. These limitations exposed the need to add other spaces where the FHS team professionals can act in an attempt to decentralize the activities and expand the possibilities for diagnostics, since its major contribution to the education sector takes to act in an integrated and coordinated manner ${ }^{(7)}$.

This assumption is in line with this proposal, since it seeks to connect health professionals working in the FHS with the school environment, through actions directed from the SHP templates. For this purpose, it is suggested that along with other matters, notions are incorporated on the SAMU and PHC concepts through an outlined educational instrument in this study. Primary care is highlighted as a privileged space to affect educational practices, the bond that builds with the population it covers.

As well as the FHS is a component of the fixed structure of pre-hospital care, SAMU is also part of the primary care network, but as mobile resource. Both are responsible for providing assistance to people in acute conditions and emergency and/or urgent, including transportation to the referral service or more complex ${ }^{(11)}$.

Studies ${ }^{(12)}$ find that the people who often call SAMU for help, make use of bad words. According to the authors, this is due to the fact that users do not understand how the service works. As a possible solution, there is the need to reduce the time of collecting the information on the phone and also the time of ambulance arrival at the scene. Another strategy would be to invest more in the explanations on the phone, remembering that the person requesting assistance is fragile, besides training the professionals working for SAMU, so they know how to deal with these behaviors.

During the development of the meetings, it was possible to identify which subjects indicate a need to clarify to the community of how SAMU works, their routines and also the differentiation between urgent and emergency care, always paying attention to the appropriateness of language, especially when it comes to actions aimed at the children.

Another frequent situation in SAMU is the fact that not every request for service is characterized as relevant service. These people receive medical advice on what to do, either through procedures that he/she can run, or through other types of referrals due to the fact he/she is not being attended by ambulance ${ }^{(13)}$. The fact is that people seeking care where it is offered, but this does not mean that they know, and blaming them for the misuse of the service does not solve the problem ${ }^{(12)}$.

Study conducted with some professionals working in $\mathrm{SAMU}^{(6)}$ reports that the main negative aspect pointed out by them is the fact that users do not understand the purpose and mission of the service. This generates unnecessary drives due to truncated information passed on by the applicant, a stressor factor for the professionals on duty, as demand increases, not to mention the large volume of prank calls. Devoting time to development actions in order to inform the population about the correct functioning of SAMU, as well as providing learning moments about what really is emergency care, reduces the vulnerability of the population, since it provides greater security in decision making on health situations and decreases in not relevant service demand, allowing it to be more efficient in the care that is necessary ${ }^{(13)}$.

In the mobile PHC, the response time is an important factor to ensure that the individual is in an urgent or emergency situation, has assisted its aggravation properly, even before the arrival of specialized care ${ }^{(14)}$. Thus, one must understand response time as the time period between the request for help and the beginning of the user service with the arrival of the team. The delay in the collection of information during the call, the medical evaluation via telemedicine, the insufficient number or unavailability of ambulances and even traffic, are factors that may increase the response time ${ }^{(15)}$.

In another study on user perceptions of the SAMU of Belo Horizonte, it was possible to identify that the subjects suggested, among other things, that there were people guiding in what situations should call the service, and specify in which cases SAMU provides care by sending ambulan$\mathrm{ce}^{(11)}$. These events confirm that the population identifies their weakness in relation to the aggregate sense to the topic urgent and emergency care, and that even this cannot have the same meaning they have for health professionals ${ }^{(16)}$. And even among health professionals this concept differs influenced by the environment in which it operates, providing frequent service to users in an emergency situation or not. This involves misuse of SAMU services and hence overloading the system ${ }^{(11)}$.

The Focus Group highlighted the need for educational instrument and a space for the information that must be transmitted on at the moment which is held by telephone request for help. This is to simply clarify what must be reported to the Technical Medical Regulation 
Assistance (TMRA) that answers the call and also subsidizes the user's conversation with the medical regulator, since this requires details of what is going to offer most appropriate response, according to the resources available at the time.

The meetings of focus groups in this study were targeted actions aimed at children, understanding that they should also receive guidance on what is an urgent and emergency situation, clearly and adequately to their ability to comprehend. After all, these individuals also access the mobile prehospital service. Sometimes they do it incorrectly, by performing fake phone calls, known as prank calls. Here, the FG highlights the importance of making the children responsible with regard to the impact that a joke or prank can entail. Issues ranging from the cost of these calls to the government, congestion on telephone lines, unnecessary mobility of ambulances and consequent lack of staff to meet real cases occurring simultaneously.

So, in an attempt to reverse this situation, it is necessary to elucidate the impact of these actions on the public service, making children collaborators of good practice and not a problem as is currently being addressed and sometimes advertised in this study. To this end, the school-age population needs to be sensitized on the importance of SAMU, how it works and even how to face an emergency and urgent situation until a specialized team reach the site. Specific topics addressed by professionals and aimed at school-age population were selected because they are urgent health aggravation, which are important in the $\mathrm{PHC}$ scenario, considering the role the school can play in this context ${ }^{(17)}$. The school is understood as a suitable place to host this initiative, as SAMU is essentially based on the integration of health services to meet the principle of integrality that is inherent ${ }^{(12)}$.

Other strategies are being developed across the country, such as the Little SAMU project, designed by SAMU of the Federal District. For being one of the few initiatives in health education area of the emergency, the comparisons were inevitable, but it is important to clarify that this study differs from the proposal of the Little SAMU project with regard to the insertion of the SHP and the FHS professionals in implementing education activities in health involving SAMU.

To develop an educational instrument from the perspective of professionals working in mobile ECS, begins a process of rapprochement of reality experienced in relation to the lack of information observed in the population. We sought to adapt the guidelines to the children, and promote the sharing of information and service, regardless of the turnover of the bond of the SAMU professionals, FHS or teachers. Another important aspect is the possibility of use in various schools, not being tied to the availability of professionals linked to the SAMU that is the Little SAMU project format, moving up to the schools to carry out the activities. This can keep going perfectly as a complementary activity to the educational instrument, or where other activities are offered. Thus, recognizing the initiative of the Little SAMU project, this study can reinforce the actions already in place, adding new proposals, professional partnerships and resources towards the same goal: to promote health education about emergency care for children.

\section{CONCLUSION}

The development of an educational instrument about SAMU, from the content discussed by health professionals that are part of its staff, has been successful, with a potential contribution to minimizing the health problems of individuals in urgent and emergency situations, from the clarification of the SAMU operation.

Specific topics addressed contribute to the clarification of the services provided, as well as notions of $\mathrm{PHC}$, whose purpose is to promote health education among the school-age population in the emergency care area. However, studies are recommended at this target population, since the contents will be decided and seized more effectively with the view of those who will appropriate them.

\section{RESUMO}

Objetivo: Sistematizar, junto aos profissionais do Serviço de Atendimento Móvel de Urgência de um município catarinense, os principais temas para a elaboração de um instrumento educativo sobre atenção às urgências, dedicado à população em idade escolar. Método: Estudo qualitativo, realizado por meio de encontros no formato de grupo focal, com 19 profissionais que desenvolvem suas atividades no Serviço de Atendimento Móvel de Urgência municipal. Os dados foram categorizados e analisados com a técnica de análise temática. Resultados: Os conteúdos debatidos nos encontros foram agrupados em quatro categorias temáticas: O Serviço de Atendimento Móvel de Urgência e a escola: educação e promoção da saúde para as crianças; Como o Serviço de Atendimento Móvel de Urgência funciona: o que é importante saber?; Tem algo errado, e agora? e; Estamos quase concluindo, dê sua opinião. Conclusão: Os temas específicos resultantes dos encontros contribuíram para a produção de um instrumento educacional sobre as atividades do Serviço de Atendimento Móvel de Urgência, que poderá ser utilizado pelo Programa Saúde na Escola para promover educação em saúde na área de atenção às urgências junto à população em idade escolar.

\section{DESCRITORES}

Serviços Médicos de Emergência; Saúde Escolar; Promoção da Saúde; Educação em Saúde; Programa Saúde da Família.

\section{RESUMEN}

Objetivo: sistematizar, con profesionales del Servicio de Atención Móvil de Urgencia del municipio de Santa Catarina, los principales problemas para el desarrollo de una herramienta educativa de atención a la sala de emergencias, dedicada a la población en edad escolar. Método: Estudio cualitativo, llevado a cabo a través de reuniones en el formato de grupos focales, con 19 profesionales que desarrollan 
sus actividades en la ciudad Servicio de Emergencia Móvil de Urgencia. Los datos fueron clasificados y analizados mediante la técnica de análisis temático. Resultados: Los contenidos tratados en las reuniones se agruparon en cuatro categorías temáticas: E1 Servicio de Emergencia Móvil y de la escuela: la educación y la promoción de la salud para los niños; Como funciona el Servicio de Atención Móvil de Urgencia:? Lo que es importante saber; Algo está mal, ¿y ahora qué? y; Estamos cerca de terminar, dar su opinión. Conclusión: Los problemas específicos que surgen de las reuniones contribuyeron a la producción de una herramienta educativa en las actividades del Servicio de Atención Móvil de Urgencia, que puede ser utilizado por el Programa de Salud Escolar para promover la educación para la salud en el área de atención a urgencias con la población los escolares.

\section{DESCRIPTORES}

Comunicación; Educación en Enfermería; Aptitud; Docentes de Enfermería; Estudiantes de Enfermería.

\section{REFERENCES}

1. Veronese AM, de-Oliveira DL, Nast K. Caracterização da demanda não pertinente ao SAMU de Porto Alegre: estudo descritivo. Online braz j nurs [Internet]. 2012 [citado 2013 abr 04]; 11 (1): 167-180. Disponível em: http://www.objnursing.uff.br/index.php/nursing/article/ view/3568. DOI: http://dx.doi.org/10.5935/1676-4285.20120015

2. Santa Catarina (Estado). Secretaria de Estado da Saúde de Santa Catarina. Programa Saúde na Escola [Internet]. Florianópolis, 2013 [citado 2013 out 10]. Disponível em: http://portalses.saude.sc.gov.br/index.php?option=com_content\&view=article\&id=2584\&ltemid=484

3. Distrito Federal. Brasil. Samu 192. Samuzinho [Internet]. Brasília; 2010 [citado 2013 maio 28]. Disponível em: http://www.samu192df. com.br/samu/ensino/samuzinho/objsamuzinho.jsp

4. Barbour R. Grupos Focais. Porto Alegre: Artmed; 2009.

5. Bardin L. Análise de conteúdo. Lisboa: Edições 70; 2010.

6. Alves M, Rocha TB da, Ribeiro HCTC, Gomes GG, Brito MJM. Specificities of the nursing work in the mobile emergency care service of Belo Horizonte. Texto contexto - enferm. [Internet]. 2013 [cited 2013 may 24]; 22(1): 208-215. Available from: http://www.scielo.br/ scielo.php?script=sci_arttext\&pid=S0104-07072013000100025\&lng=en

7. Maciel ELN, Oliveira CB, Frechiani JM, Sales CMM, Brotto LD de A, Araújo MD. Projeto Aprendendo Saúde na Escola: a experiência de repercussões positivas na qualidade de vida e determinantes da saúde de membros de uma comunidade escolar em Vitória, Espírito Santo. Ciênc. saúde coletiva [Internet]. 2010 [citado 2013 maio 25]; 15(2): 389-396. Disponível em: http://www.scielosp.org/scielo. php?script=sci_arttext\&pid=S1413-81232010000200014\&lng=en

8. Galvão DMPG, Silva IA da. A amamentação nos manuais escolares de estudo do meio do $1^{\circ}$ ciclo do ensino básico. Rev. Enf. Ref. [Internet]. 2011 [citado 2012 maio 25]; serlll(4):7-16. Disponível em: http://www.scielo.mec.pt/scielo.php?script=sci_arttext\&pid=S0874$-02832011000200001 \& \operatorname{lng}=\mathrm{pt}$

9. Maia ER, Lima JrJF, Pereira J dos S, Eloi A de C, Gomes C das C, Nobre MMF. Validação de metodologias ativas de ensino-aprendizagem na promoção da saúde alimentar infantil. Rev. Nutr. [Internet]. 2012 [citado 2013 maio 25]; 25(1):79-88. Disponível em: http://www. scielo.br/scielo.php?script=sci_arttext\&pid=S1415-52732012000100008\&lng=en

10. Pires MRGM, Göttems LBD, Cupertino TV, Leite LS, Vale LR do, Castro MA de et al . A utilização dos serviços de atenção básica e de urgência no sus de belo horizonte: problema de saúde, procedimentos e escolha dos serviços. Saude soc. [Internet]. 2013 [citado 2013 maio 22]; 22(1):211-222. Disponível em: http://www.scielo.br/scielo.php?script=sci_arttext\&pid=S0104-12902013000100019\&lng=en

11. Alves M, Rocha RLP, Rocha TB da, Gomes GG. Percepções de usuários sobre o serviço de atendimento móvel de urgência de Belo Horizonte. Cienc. Cuid. Saúde. [Internet]. 2010 [citado 2013 maio 25]; 9(3):543-551. Disponível em: http://www.periodicos.uem.br/ojs/ index.php/CiencCuidSaude/article/view/10273

12. O'Dwyer G, Mattos RA. Cuidado integral e atenção às urgências: o serviço de atendimento móvel de urgência do estado do Rio de Janeiro. Saude soc. [Internet]. 2013 mar [citado 2013 maio 22]; 22(1):199-210. Disponível em: http://www.scielo.br/scielo.php?script=sci_ arttext\&pid=S0104-12902013000100018\&lng=en

13. Veronese AM, Oliveira DLLC de, Rosa IM da, Nast K. Oficinas de primeiros socorros: relato de experiência. Rev. Gaúcha Enferm. [Internet]. 2010 [citado 2013 maio 24]; 31(1):179-182. Disponível em: http://www.scielo.br/scielo.php?script=sci_arttext\&pid=S1983$-14472010000100025 \& \operatorname{lng}=\mathrm{en}$

14. Pergola AM, Araujo IEM. Laypeople and basic life support. Rev. esc. enferm. USP [Internet]. 2009 [cited 2015 Nov 28]; 43(2): 335-342. Available from: http://www.scielo.br/pdf/reeusp/v43n2/en_a12v43n2.pdf

15. Pitteri JSM, Monteiro PS. Caracterização do Serviço de Atendimento Móvel de Urgência SAMU em Palmas-Tocantins, Brasil, em 2009. [dissertation]. [Brasília]: Faculdade de Ciências da Saúde da Universidade de Brasília; 2010. 124p. Disponível em: http://repositorio.unb. br/bitstream/10482/9149/1/2010_JessimiraSoaresMunizPitteri.pdf

16. Machado CV, Salvador FGF, O’Dwyer G. Serviço de Atendimento Móvel de Urgência: análise da política brasileira. Rev. Saúde Pública [Internet]. 2011 [citado 2013 maio 23]; 45(3):519-528. Disponível em: http://www.scielosp.org/scielo.php?script=sci_arttext\&pid=S0034$-89102011000300010 \& \operatorname{lng}=e n$. EpubApr15, 2011

17. Mota LL, Andrade SR de. Topics of pre-hospital care for schoolchildren: the perspective of professionals of the Mobile Emergency Care Service (SAMU). Texto contexto-enferm. [Internet]. 2015 [cited 2015 nov 28]; 24(1):38-46. Available from: http://www.scielo.br/scielo. php?script=sci_arttext\&pid=S0104-07072015000100038\&lng=en. http://dx.doi.org/10.1590/0104-07072015000500014 